\title{
Penerapan Model Pembelajaran Kooperatif Tipe STAD untuk Meningkatkan Aktivitas dan Hasil Belajar
}

\author{
Made Suparmini ${ }^{1^{*}}$ \\ ${ }^{1} S D$ Negeri 1 Busungbiu, Singaraja, Indonesia
}

\section{A R T I C L E I N F O}

Article history:

Received 01 October 2020

Received in revised form

25 November 2020

Accepted 10 January 2021

Available online 01

February 2021

\section{Kata Kunci:}

STAD, Hasil belajar,

Aktivitas

Keywords:

STAD,

Learning Outcome,

Activities

\begin{abstract}
A B S T R A K
Rendahnya hasil belajar siswa diakibatkan dengan penggunaan model pembelajaran yang monoton yang menimbulkan rasa bosan dan serta siswa tidak aktif dalam kegiatan pembelajaran. Penelitian ini bertujuan meningkatkan aktivitas dan hasil belajar Penjasorkes melalui penerapan model pembelajaran kooperatif tipe STAD pada siswa kelas VI SD. Penelitian ini adalah penelitian tindakan kelas yang melibatkan siswa kelas VI yang berjumlah 30 orang siswa. Dalam penelitian ini data hasil belajar siswa dikumpulkan dengan lembar observasi, metode analisis data dengan analisis deskriptif. Hasil penelitian ini menunjukan bahwa (1) nilai rata-rata aktivitas belajar mengalami peningkatan dari 52 pada hasil belajar prasiklus dengan kategori kurang aktif menjadi 71 dengan kategori cukup aktif pada siklus I, kemudian meningkat menjadi 90 dengan kategori sangat aktif pada siklus II, (2) hasil belajar dinyatakan meningkat, hal dibuktikan terjadi perbedaan hasil belajar antara prasiklus ((jumlah 1692, rata-rata 56, daya serap 56\%, ketuntasan belajar $17 \%$ ), siklus I (jumlah 1175, rata-rata 73, daya serap 73\%, ketuntasan belajar $63 \%$ ) dan siklus II (jumlah 1275, rata-rata 80 , daya serap $80 \%$, ketuntasan belajar $100 \%$ ). Terjadi peningkatan hasil belajar antara siklus I dan siklus II, menunjukan kenaikan rata-rata daya serap 7\% dan pada ketuntasan belajar mengalami kenaikan sebesar 37\%. Kesimpulan penerapan model pembelajaran kooperatif tipe STAD pada siswa kelas VI SD Negeri dapat meningkatkan aktivitas dan hasil belajar.
\end{abstract}

\section{A B S T R A K}

Low student learning outcomes are caused by the use of monotonous learning models that cause boredom and students are not active in learning activities. This study aims to increase the activities and learning outcomes of Physical Education and Sports through the application of the STAD type cooperative learning model to grade VI SD students. This research is a classroom action research involving 30 class VI students. In this study, data on student learning outcomes were collected using observation sheets, the method of data analysis was descriptive analysis. The results of this study indicate that (1) the average value of learning activities has increased from 52 in the pre-cycle learning outcomes with the less active category to 71 with the fairly active category in the first cycle, then increased to 90 with the very active category in the second cycle, (2) The learning outcomes of subjects are stated to have increased, this is evidenced by differences in learning outcomes between pre-cycle (total 1692, average 56, absorption capacity 56\%, learning completeness $17 \%$ ), cycle I (total 1175, average 73, power absorption 73\%, learning completeness 63\%) and cycle II (total 1275, average 80 , absorption $80 \%$, learning completeness $100 \%$ ). There was an increase in learning outcomes between cycle I and cycle II, indicating an increase in the average absorption $7 \%$ and the learning completeness has increased by $37 \%$. The conclusion is that the application of the STAD type cooperative learning model in class VI SD Negeri students can increase the activities and learning outcomes. 


\section{Pendahuluan}

Pembelajaran adalah salah satu prose interaksi antara siswa dan sumber belajar. Pembelajaran yang baik adalah pembelajaran yang memberikan kesempatan kepada siswa untuk belajar secara mandiri dan membangun pengetahunya sendiri (Mardiana et al., 2020; Wirdaningsih et al., 2017). Pemilihan model pembelajaran yang tepat dapat mendorong siswa untuk belajar secara aktif dan menumbuhkan rasa senang siswa terhadap pelajaran sehingga siswa dapat meraih hasil belajar dan prestasi yang optimal (Hasanah et al., 2019; Juraini et al., 2017). Setiap model pembelajaran mengarahkan ke dalam mendesain pembelajaran untuk membantu siswa sedemikian rupa sehingga tujuan pembelajaran tercapai (Armansyah, 2014). Pembelajaran dikategorikan berhasil apabila setiap siswa mampu menerima materi pelajaran dengan baik dan benar serta mencerminkan keseriusan dalam mengikuti proses pembelajaran. Namun dalam kenyataannya di lapangan, proses pembelajaran masih berlangsung dengan monoton, siswa hanya aktif ketika mendapatkan pengarahan dari guru yang berarti guru lebih senang mengajar dengan metode ceramah. Siswa ditempatkan sebagai obyek belajar yang hanya disuruh untuk belajar sesuai dengan petunjuk guru. Siswa kurang mendapatkan kesempatan untuk menemukan konsep atau materi secara mandiri sehingga siswa hanya pasif dan menerima materi pembelajaran. Dalam praktiknya, dalam pembelajaran penjasorkes guru selalu menugaskan siswa satu persatu untuk melakukan gerakan sesuai dengan materi yang menyebabkan sikap siswa menjadi individualistis yaitu tidak mau membantu temannya yang belum bisa melakukan gerakan yang dicontohkan oleh guru. Disamping itu, guru yang selalu mengawasi siswa, memantau dan mengoreksi pelaksanaan latihan yang dilakukan siswa sehingga proses pembelajaran dirasakan sangat melelahkan bagi guru, hal ini disebabkan karena proses pembelajaran masih terpusat pada guru. Dengan kondisi pembelajaran seperti di atas, berpengaruh pada hasil belajar siswa yang juga ikut rendah. Pada pembelajaran awal yang dilakukan pada tanggal 20 Juli 2017, setelah menerangkan materi pelajaran dengan menggunakan metode yang konvensional, dilanjutkan dengan evaluasi yang dilakukan dengan lembar observasi didapatkah rata-rata hasil belajar sebesar 56, daya serap sebesar 56\% dengan ketuntasan belajar sebesar 17\%. Salah satu penyebab rendahnya hasil belajar siswa adalah penggunaan model pembelajaran yang diterapkan(Kurniawan et al., 2018). Jika masalah ini dibiarkan akan berdampak terhadap hasil belajar.

Hasil belajar adalah segala hasil yang diperoleh oleh siswa setelah melakukan proses belajar. Hasil belajar terdiri atas tiga perubahan yaitu pengetahuan, sikap dan keterampilan. Hasil belajar adalah salah satu cara yang bisa digunkan sebagai tolak ukur keberhasilan proses pembelajaran. Hasil belajar yang optimal bisa dihujudkan dengan menerapkan model-model pembelajaran yang inovatif (Ayu et al., 2016; Sudiani et al., 2014). Pembelajaran yang menyenangkan dapat membantu siswa untuk meningkatkan hasil belajar siswa (Hidayatin, 2016). Salah satu model pembelajaran yang bisa digunakan adalah model pembelajaran koperatif STAD. Model pembelajaran STAD adalah salah satu model pembelajaran kooperatif yang lebih menekankan proses interaksi antar siswa dengan teman sebayanya. Model pembelajaran kooperatif model STAD akan memberikan kesempatan kepada siswa untuk berdiskusi dalam kelompok kelas sehingga akan tercipta suasana belajar yang lebih aktif, efektif dan menyenangkan(Fiteriani \& Baharudin, 2017; Primartadi, 2013). Model pembelajaran kooperatif model STAD adalah salah satu model pembelajaran yang berguna untuk menumbuhkan kemampuan kerjasama, kreatif, berpikir kritis dan ada kemampuan untuk membantu teman(Gusniar, 2013; Nikmah et al., 2016). Aktivitas pembelajaran kooperatif menekankan pada aktivitas dan interaksi diantara peserta didik untuk saling memotivasi dan saling membantu dalam menguasai materi pelajaran guna mencapai prestasi yang maksimal (Yuniarti, 2018). STAD dikembangkan untuk mencapai tiga tujuan pembelajaran penting yaitu hasil belajar akademik, penerimaan terhadap keragaman atau perbedaan individu dan pengembangan keterampilan sosial (Sukiyanto, 2018). Pembelajaran STAD akan membantu dalam meningkatkan hasil belajar, aktivitas siswa, guru dan respon siswa (Nugroho \& Shodikin, 2018). model STAD menekankan pada aktivitas dan interaksi antara siswa untuk saling membantu dalam menguasai materi pelajaran, guna mencapai tujuan yang diharapkan, siswa di tempatkan dalam tim belajar agar bekerja sama dalam kelompok untuk menyelesaikan tugas yang diberikan oleh guru.

Mengacu pada permasalahan di atas, maka sangat penting bagi guru untuk memperbaiki hasil belajar siswa yang masih rendah dengan menerapkan model pembelajaran yang tepat, sehingga dapat memacu siswa untuk dapat berperan aktif terhadap materi pelajaran. Oleh karena itu, peneliti mengambil sebuah sikap untuk menerapkan model pembelajaran kooperatif tipe STAD. Penelitian ini bertujuan meningkatkan aktivitas dan hasil belajar Penjasorkes melalui penerapan model pembelajaran kooperatif tipe STAD pada siswa kelas VI SD Negeri 1 Busungbiu semester I tahun pelajaran 2017/2018. Penerapan model pembelajaran kooperatif merupakan strategi pembelajaran yang terstruktur dan sistematis, dimana kelompok-kelompok kecil bekerja sama untuk mencapai tujuan bersama. Pembelajaran kooperatif merupakan metode pembelajaran yang melibatkan kelompok-kelompok kecil yang heterogen dan belajar 
bersama untuk mencapai tujuan-tujuan dan tugas-tugas akademik bersama, sementara sambil bekerja sama belajar keterampilan-keterampilan kolaboratif dan sosial.

\section{Metode}

Penelitian ini menggunakan jenis penelitian tindakan kelas yang berdasarkan pada model penelitian tindakan Kanca (2010:4). Penelitian ini dilaksanakan di SD Negeri 1 Busungbiu dengan alamat Banjar Dinas Kaja, Desa Busungbiu, Kecamatan Busungbiu, Kabupaten Buleleng. Penelitian ini dilaksanakan pada semester I tahun pelajaran 2017/2018 selama 4 bulan dari bulan Juli sampai dengan Oktober 2017. Subjek penelitian ini adalah siswa kelas VI SD Negeri 1 Busungbiu semester I tahun pelajaran 2017/2018 yang berjumlah 30 orang, terdiri atas 17 orang laki-laki dan 13 orang perempuan. Penelitian ini dilakukan bersiklus. Setiap siklus terdiri dari empat tahapan, yaitu perencanaaan, pelaksanaan tindakan, pengamatan, dan refleksi. Dari keempat tahap yang dilakukan pada penelitian ini dapat digambarkan seperti Gambar 1.

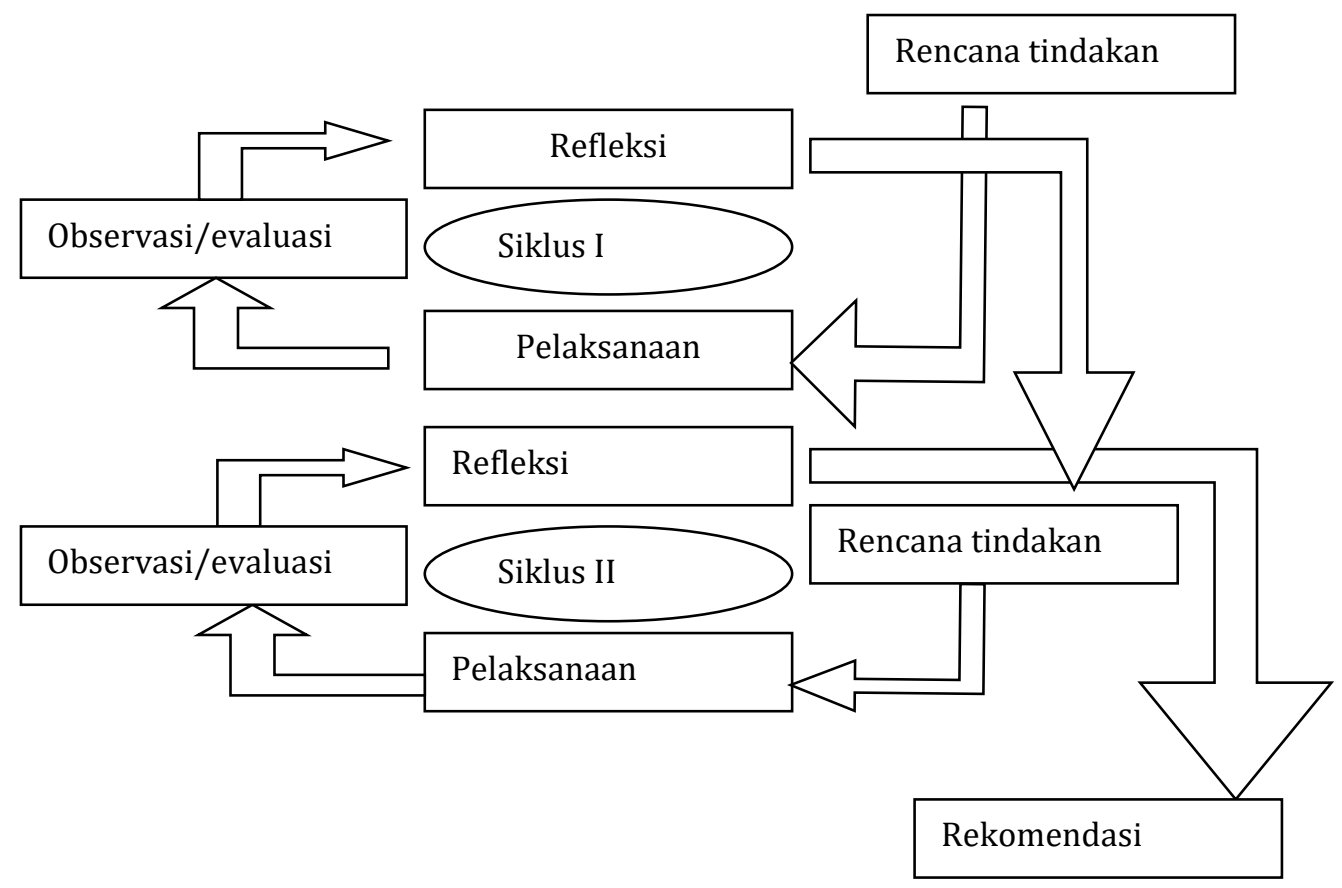

Gambar 1. Rancangan PTK

Penelitian tindakan kelas ini dilaksanakan sesuai dengan rancangan penelitian seperti pada gambar di atas. Penelitian ini dimulai dari siklus I dimulai dengan perencanaan seperti: (1) membuat RPP yang sesuai dengan sintaks model pembelajaran kooperatif tipe STAD, (2) menyiapkan media, sarana dan prasarana yang diperlukan, (3) menyiapkan lembar observasi siswa. Pada tahap pelaksanaan, peneliti melaksanakan semua perencanaan pembelajaran yang telah disusun. Secara garis besar pelaksanaan proses pembelajaran adalah: (1) menyajikan informasi kepada siswa dengan jalan demonstrasi atau lewat bahan bacaan, (2) menjelaskan kepada siswa cara membentuk kelompok belajar dan membantu setiap kelompok agar melakukan transisi secara efisien, (3) membimbing kelompok-kelompok belajar pada saat mereka mengerjakan tugas mereka, (4) mengevaluasi hasil belajar tentang materi materi yang telah dipelajari atau masing-masing kelompok mempresentasikan hasil kerjanya, (5) mencari cara-cara untuk menghargai baik upaya maupun hasil belajar individu dan kelompok. Obervasi dan evaluasi merupakan suatu cara untuk mengamati atas hasil atau dampak dari tindakan yang dilaksanakan atau ditekankan terhadap siswa. Fungsi observasi atau evaluasi adalah untuk mendokumentasikan implikasi tindakan yang diberikan kepada subyek (Kanca, 2010:126). Sementara Refleksi merupakan suatu upaya mengkaji, melihat, dan mempertimbangkan atas hasil atau dampak dari tindakan berbagai criteria (Kanca, 2010:126). Setelah dilakukan evaluasi pembelajaran, kekurangan yang dialami siswa dalam proses pembelajaran, maka peneliti mencari solusi pemecahan masalah yang menghambat dalam proses pembelajaran. 
Metode pengumpulan data dalam penelitian ini adalah ada dua yakni dengan metode observasi. Untuk pengumpulan data mengenai hasil belajar siswa, peneliti menggunakan lembar observasi. Hasil belajar penjaskes siswa dilakukan ketika proses pengambilan nilai. alat yang digunakan yaitu format assesmen penjaskes dengan memberikan penilaian/skor yang sesuai dengan kemapuan siswa berdasarkan assesment hasil belajar penjaskes. Hasilnya dikumpulkan pada setiap akhir siklus untuk mengetahui siswa mana yang mendapatkan nilai terbaik. Data yang menyangkut hasil belajar siswa, dianalisis menggunakan analisis deskriptif yaitu dengan mencari rata-rata nilai siswa, daya serap dan ketuntasan belajar siswa. Setelah memperoleh rata-rata aktivitas belajar siswa, selanjutnya rata-rata tersebut dimasukkan ke dalam kriteria keberhasilan siswa seperti pada Tabel 1.

Tabel 1. Kriteria Keberhasilan Aktivitas Siswa

\begin{tabular}{ll}
\hline Pencapaian Skor Pembelajaran & Kategori \\
\hline $85-100$ & Sangat Aktif (SA) \\
$75-84$ & Aktif (A) \\
$65-74$ & Cukup Aktif (CA) \\
$45-64$ & Kurang Aktif (KA) \\
$0-44$ & Kurang Aktif Sekali (KAS) \\
\hline
\end{tabular}

\section{Hasil dan Pembahasan}

Berdasarkan hasil penelitian dengan penerapan model pembelajaran kooperatif tipe STAD dalam pembelajaran penjasorkes pada siswa kelas VI SD Negeri 1 Busungbiu semester I tahun pelajaran 2017/2018, disajikan pada Tabel 2.

Tabel 2. Perkembangan Hasil Belajar

\begin{tabular}{cccc}
\hline Uraian & Prasiklus & Siklus I & Siklus II \\
\hline Jumlah & 1692 & 1175 & 1275 \\
Rata-rata & 56 & 73 & 80 \\
Daya Serap & $56 \%$ & $73 \%$ & $80 \%$ \\
Ketuntasan Belajar & $17 \%$ & $63 \%$ & $100 \%$ \\
\hline
\end{tabular}

Berdasarkan Tabel 2 di atas, dapat dijelaskan bahwa nilai rata-rata kelas mengalami peningkatan dari 56 pada hasil belajar prasiklus menjadi 73 pada siklus I, kemudian meningkat menjadi 80 pada siklus II. Sedangkan nilai daya serap siswa juga mengalami peningkatan dari $56 \%$ pada prasiklus meningkat menjadi $73 \%$ pada siklus I, kemudian meningkat menjadi $80 \%$ pada siklus II. Ketuntasan belajar juga mengalami peningkatan dari $17 \%$ pada hasil belajar prasiklus, naik menjadi $63 \%$ pada siklus I, kemudian meningkat menjadi $100 \%$ pada siklus II. Sementara untuk rekapitulasi aktivitas belajar siswa dalam mengikuti pembelajaran dengan penerapan model pembelajaran kooperatif tipe STAD dapat dilihat pada Tabel 3.

Tabel 3. Perkembangan Aktivitas Belajar

\begin{tabular}{lrrrr}
\hline & Uraian & Prasiklus & Siklus I & Siklus II \\
\hline Jumlah & 1563 & 2144 & 2713 \\
Rata-rata (M) & 52 & 71 & 90 \\
Kategori & Kurang Aktif & Cukup Aktif & Sangat Aktif & \\
\hline
\end{tabular}

Berdasarkan Tabel 3 di atas, dapat dijelaskan bahwa nilai rata-rata aktivitas belajar mengalami peningkatan dari 52 pada hasil belajar prasiklus dengan kategori kurang aktif menjadi 71 dengan kategori cukup aktif pada siklus I, kemudian meningkat menjadi 90 dengan kategori sangat aktif pada siklus II. Pada prasiklus, hasil belajar diperoleh dari pembelajaran awal. Hasil belajar prasiklus dengan rata-rata 56, daya serap 56\% dengan ketuntasan belajar sebesar $17 \%$ sementara untuk rata-rata aktivitas belajar siswa sebesar 52 dengan kategori kurang aktif, bila hasil belajar ini dibandingkan dengan indikator keberhasilan dalam penelitian ini, maka hasil belajar tersebut masih belum memenuhi indikator tersebut. Rendahnya hasil belajar pada observasi awal disebabkan oleh peneliti menerapkan metode tradisional. Pembelajaran berlangsung monoton karena metode tersebut berlangsung terus menerus selama ini, sehingga siswa kurang mendapatkan kesempatan untuk menemukan konsep atau materi secara mandiri 
sehingga siswa hanya pasif dan menerima materi pembelajaran. Pada siklus I, hasil belajarnya dengan rata-rata 73 daya serap $73 \%$ dengan ketuntasan belajar sebesar $63 \%$ sementara untuk aktivitas belajar sebesar 71 dengan kategori cukup aktif. Hasil belajar ini belum memenuhi indikator keberhasilan karena (1) dominasi siswa-siswi yang terampil bermain sepak bola membuat mereka yang belum terampil dalam melakukan gerak dasar bola basket, bahkan cenderung lemah keterampilannya merasa tidak percaya diri dalam bermain bola basket. Hal tersebut menyebabkan siswa yang kurang terampil menjadi pasif dalam pembelajaran, (2) interaksi belajar belum maksimal, keterlibatan siswa juga belum maksimal, sehinga secara keseluruhan proses pembeljaran belum bisa mencapai target yang diharapkan, (3) beberapa siswa menganggap bermain bola basket adalah permainan yang sulit dilakukan karena ada beberapa teknik dasar sepak bola sulit dilakukan oleh siswa. Pada siklus II, hasil belajar siswa dengan rata-rata 80 daya serap $80 \%$ dengan ketuntasan belajar sebesar $100 \%$, bila hasil belajar ini bila dibandingkan dengan indikator keberhasilan yakni hasil belajar sebesar 75, daya serap sebesar 75\% dengan ketuntasan belajar sebesar 85\% sementara rata-rata aktivitas belajar siswa pada siklus II sebesar 90 dengan kategori sangat aktif, maka hasil belajar ini telah memenuhi indikator keberhasilan.

Adapun penyebab hasil belajar siswa sudah meningkat karena (1) siswa yang terampil diberikan tugas untuk membimbing temannya sehingga semua siswa memiliki keterampilan yang sama, (2) siswa senang bermain teknik dasar tolak peluru, (3) siswa semakin semangat dengan hadiah yang dijanjikan oleh peneliti, dan (4) materi yang disampaikan oleh peneliti sudah diperhatikan oleh siswa. Peningkatan hasil belajar siswa disebabkan oleh penerapan model pembelajaran kooperatif tipe STAD memiliki beberapa keunggulan yakni (1) siswa lebih mampu mendengarkan, menerima, dan menghormati serta menerima orang lain, (2) aktivitas belajar selama kegiatan proses pembelajaran nampak bebas, ceria bergairah, dan kondusif, (3) siswa mudah memecahkan masalah yang dihadapi mengerjakan tugas secara mandiri maupun kelompok, (4) siswa lebih terangsang dan terbiasa mengerjakan tugas secara mandiri maupun kelompok, (5) siswa dapat menerima pengalaman dan dimengerti orang lain, (6) dapat menumbuhkan sikap siswa untuk lebih tertarik, tidak mudah menyerah dan aktif menyelesaikan tugas, dan (7) dapat berkolaborasi dengan teman. Hal ini tidak terlepas dari penerapan model pembelajaran STAD. Karena penerapan model pembelajaran STAD dapat membuat suasana pembelajaran lebih menyenangkan yang berdampak terhadap hasil belajar dan keaktifan siswa dalam proses pembelajaran.

Hasil belajar yang optimal bisa dihujudkan dengan menerapkan model-model pembelajaran yang inovatif (Ayu et al., 2016; Sudiani et al., 2014). Pembelajaran yang menyenangkan dapat membantu siswa untuk meningkatkan hasil belajar siswa (Hidayatin, 2016). Salah satu model pembelajaran yang bisa digunakan adalah model pembelajaran koperatif STAD. Model pembelajaran STAD adalah salah satu model pembelajaran kooperatif yang lebih menekankan proses interaksi antar siswa dengan teman sebayanya. Model pembelajaran kooperatif model STAD akan memberikan kesempatan kepada siswa untuk berdiskusi dalam kelompok kelas sehingga akan tercipta suasana belajar yang lebih aktif, efektif dan menyenangkan(Fiteriani \& Baharudin, 2017; Primartadi, 2013). Model pembelajaran kooperatif model STAD adalah salah satu model pembelajaran yang berguna untuk menumbuhkan kemampuan kerjasama, kreatif, berpikir kritis dan ada kemampuan untuk membantu teman(Gusniar, 2013; Nikmah et al., 2016). Aktivitas pembelajaran kooperatif menekankan pada aktivitas dan interaksi diantara peserta didik untuk saling memotivasi dan saling membantu dalam menguasai materi pelajaran guna mencapai prestasi yang maksimal (Yuniarti, 2018). STAD dikembangkan untuk mencapai tiga tujuan pembelajaran penting yaitu hasil belajar akademik, penerimaan terhadap keragaman atau perbedaan individu dan pengembangan keterampilan sosial (Sukiyanto, 2018). Pembelajaran STAD akan membantu dalam meningkatkan hasil belajar, aktivitas siswa, guru dan respon siswa (Nugroho \& Shodikin, 2018). Model STAD menekankan pada aktivitas dan interaksi antara siswa untuk saling membantu dalam menguasai materi pelajaran, guna mencapai tujuan yang diharapkan, siswa di tempatkan dalam tim belajar agar bekerja sama dalam kelompok untuk menyelesaikan tugas yang diberikan oleh guru. Hasil penelitian ini diperkuat dengan hasil penelitian yang dilakukan sebelumnya.

Penelitian yang dilakukan oleh Kusumawardani et al., (2018) menunjukkan bahwa menunjukan bahwa terdapat perbedaan pada hasil belajar siswa setelah menggunakan media poster pada model kooperatif tipe STAD dalam kegiatan belajar mengajar yang telah dilakukan. Sehingga dapat disimpulkan bahwa pembelajaran dengan menggunakan media poster pada model kooperatif tipe STAD efektif terhadap hasil belajar matematika siswa. Penelitian yang dilakukan Sari et al., (2018)menunjukkan bahwa (1) terdapat perbedaan hasil belajar IPA dan self efficacy siswa yang menggunakan model pembelajaran kooperatif STAD berbantuan mind map dan model pembelajaran langsung, (2) terdapat perbedaan hasil belajar IPA siswa yang belajar dengan model kooperatif STAD berbantuan mind map dan model pembelajaran langsung, (3) terdapat perbedaan self efficacy siswa yang belajar dengan model kooperatif STAD berbantuan mind map dan model pembelajaran langsung. Penelitian Navisha et al., (2017) menunjukkan model pembelajaran kooperatif tipe Student Teams Achievement Division (STAD) 
berbantuan media video pembelajaran tentang Perjuangan Kemerdekaan Indonesia berpengaruh terhadap hasil belajar IPS siswa kelas V di SD Gugus V Kecamatan Kubutambahan Tahun Pelajaran 2016/2017. Berdasarkan jabaran tersebut dapat dikatakan bahwa model pembelajaran STAD yang diterapkan dapat meningkatkan aktivitas belajar siswa yang tentunya berdampak terhadap hasil belajar siswa. Penerapan model ini bisa digunakan sebagai solusi yang baik untuk mengatasi pembelajaran yang berkaitan dengan hasil belajar.

\section{Simpulan dan Saran}

Berdasarakan hasil penelitian dan pembahasan yang sudah dijabarakan sebelunya, terjadi peningkatkan aktivitas dan hasil belajar siswa dari hasil observasi awal, Siklus I dan Siklus II setelah diterapkan model pembelajaran kooperatif STAD. Penerapan model pembelajaran kooperatif merupakan strategi pembelajaran yang terstruktur dan sistematis, dimana kelompok-kelompok kecil bekerja sama untuk mencapai tujuan bersama. Pembelajaran kooperatif merupakan metode pembelajaran yang melibatkan kelompok-kelompok kecil yang heterogen dan belajar bersama untuk mencapai tujuan-tujuan dan tugas-tugas akademik bersama, sementara sambil bekerja sama belajar keterampilan-keterampilan kolaboratif dan sosial

\section{Daftar Rujukan}

Armansyah, A. (2014). Pengaruh Penerapan Model Pembelajaran Cooperative Script Terhadap Hasil Belajar Siswa Pada Mata Pelajaran Biologi Kelas VIII4 SMP Negeri 1 Makasar. Jurnal Nalar Pendidikan, 2(1), 12-17. http://ojs.unm.ac.id/nalar/article/download/1962/946.

Ayu, I. G., Perdani, M., Gading, K., \& Riastini, P. N. (2016). Pengaruh Model Pembelajaran Word Square Terhadap Hasil Belajar IPA Pada Siswa Bermotivasi Belajar Berbeda di Kelas IV SD. E-Journal PGSD Universitas Pendidikan Ganesha, 4(1-10).

Fiteriani, I., \& Baharudin. (2017). Analisis perbedaan hasil belajar kognitif menggunakan metode pembelajaran kooperatif yang berkombinasi pada materi ipa di min Bandar Lampung. Jurnal $\begin{array}{llll}\text { Pendidikan Dan Pembelajaran } & \text { Dasar, } & \text { 1-30. }\end{array}$ http://ejournal.radenintan.ac.id/index.php/terampil/article/viewFile/2224/1669.

Gusniar. (2013). Penerapan Model Pembelajaran Kooperatif Tipe Student Teams Achievment Division (STAD) Dalam Meningkatkan Hasil Belajar Siswa Pada Mata Pelajaran IPS Kelas IV SDN No. 2 Ogoamas II. Jurnal Kreatif Tadulako Online, 2(1), 198-221. http://jurnal.untad.ac.id/jurnal/index.php/JKTO/article/viewFile/3005/2081.

Hasanah, N. F., Nurtaman, M. E., \& Hanik, U. (2019). Pengaruh Model Pembelajaran Kooperatif Tipe Rotating Trio Exchange (Rte) Terhadap Hasil Belajar Dan Minat Belajar Matematika Siswa Kelas V Sdn Pinggir Papas 1 Sumenep. Widyagogik: Jurnal Pendidikan Dan Pembelajaran Sekolah Dasar, 6(2), 112. https://doi.org/10.21107/widyagogik.v6i2.5195.

Hidayatin, N. (2016). Pengaruh Pendekatan Contextual Teaching and Learning (Ctl) Terhadap Hasil Belajar Matematika. Buana Matematika : Jurnal Ilmiah Matematika Dan Pendidikan Matematika, 6(1:), 49-56. https://doi.org/10.36456/buanamatematika.v6i1:377.

Juraini, J., Taufik, M., \& Gunada, I. W. (2017). Pengaruh Model Pembelajaran Kooperatif Tipe STAD (Student Team Achievement Division) dengan Metode Eksperimen Terhadap Keterampilan Proses Sains dan Hasil Belajar Fisika pada Siswa SMA Negeri 1 Labuapi Tahun Pelajaran 2015/2016. Jurnal Pendidikan Fisika Dan Teknologi, 2(2), 80. https://doi.org/10.29303/jpft.v2i2.293.

Kurniawan, H. R., Elmunsyah, H., \& Muladi, M. (2018). Perbandingan Penerapan Model Pembelajaran Project Based Perbandingan Penerapan Model Pembelajaran Project Based Learning Dan Think Pair Share Berbantuan Modul Ajar Terhadap Kemandirian Dan Hasil Belajar Siswa Kelas XI di SMKN 3 Malang. Jurnal Pendidikan (Teori Dan Praktik), 3(2), 80. https://doi.org/10.26740/jp.v3n2.p80-85.

Kusumawardani, N., Siswanto, J., \& Purnamasari, V. (2018). Pengaruh Model Pembelajaran Kooperatif Tipe STAD Berbantuan Media Poster Terhadap Hasil Belajar Peserta Didik. Jurnal Ilmiah Sekolah Dasar, 2(2). https://doi.org/10.23887/jisd.v2i2.15487.

Mardiana, M., Deswita, H., \& Isharyadi, R. (2020). Pengaruh Model Pembelajaran CORE (Connecting, 
Organizing, Reflecting, Extending) Terhadap Kemampuan Koneksi Matematis Siswa Kelas VIII SMP N 3 Rambah. Jurnal Absis : Jurnal Pendidikan Matematika Dan Matematika, 2(2), 180-187. https://doi.org/10.30606/absis.v2i2.390.

Navisha, R. I., Tastra, I. D. K., \& Dibia, I. K. (2017). Pengaruh Model Stad Berbantuan Media Video Pembelajaran Terhadap Hasil Belajar Ips Siswa Sd Kelas V. MIMBAR PGSD Undiksha, 5(2). https://doi.org/10.23887/jjpgsd.v5i2.10935.

Nikmah, E. H., Fatchan, A., \& Wirahayu, Y. A. (2016). Model Pembelajaran Student Teams Achievement Divisions (STAD), Keaktifan dan Hasil Belajar Siswa. Jurnal Pendidikan Geografi, 3(3), 1-17. http://jurnal-online.um.ac.id/data/artikel/artikelE91D7FB9C21685AA36E47BE7A44B0CC7.pdf.

Nugroho, S., \& Shodikin, A. (2018). Keefektifan Pembelajaran Student Teams Achievement Division ( Stad) Berbantuan Komik ( Learning Effectiveness of Student Teams Achievement. Jurnal Matematika $\begin{array}{llll}\text { Dan } & \text { Pendidikan 22-32. }\end{array}$ https://doi.org/https://doi.org/10.26594/jmpm.v3i1.1067.

Primartadi, A. (2013). Pengaruh metode student teams-achievement division (STAD) dan problem based learning terhadap hasil belajar ditinjau dari potensi akademik siswa SMK otomotif. Jurnal Pendidikan Vokasi, 2(2), 143-153. https://doi.org/10.21831/jpv.v2i2.1024.

Sari, N. P. I. K., Arnyana, I. B. P., \& Mardana, I. B. P. (2018). Pengaruh Model Pembelajaran Kooperatif Stad Berbantuan Mind Map Terhadap Hasil Belajar Ipa Dan Self Efficacy Siswa Kelas Viii Smp. Jurnal Imiah Pendidikan Dan Pembelajaran, 2(2), 229-236. https://doi.org/10.23887/jipp.v2i2.15607.

Sudiani, N. L., Dantes, N., \& Kusmariyatni, N. (2014). Pengaruh Model Pembelajaran Word Square Terhadap Hasil Belajar IPA dengan Kovariabel Kemampuan Berpikir Kritis. 2(1).

Sukiyanto, S. (2018). Pengembangan Rencana Pembelajaran Matematika Dengan Model Kooperatif Tipe Stad Dan Teori Vygotsky. De Fermat: Jurnal Pendidikan Matematika, 1(2), 31-41. https://doi.org/10.36277/defermat.v1i2.24.

Wirdaningsih, S., Arnawa, I. M., \& Anhar, A. (2017). Pengembangan Perangkat Pembelajaran Matematika dengan Pendekatan Contextual Teaching and Learning untuk Meningkatkan Kemampuan Pemecahan Masalah Peserta Didik Kelas XI. JNPM (Jurnal Nasional Pendidikan Matematika), 1(2), 275. https://doi.org/10.33603/jnpm.v1i2.535.

Yuniarti, D. (2018). Pengaruh Model Student Teams Achievement Divisions ( STAD ) Berbantuan Media Mind Mapping Terhadap Hasil Belajar IPS Siswa Kelas V SD Gugus III Kuta Utara Badung Tahun

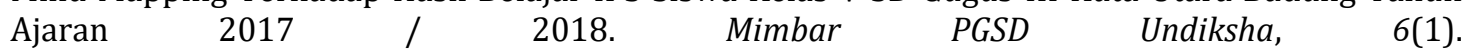
https://doi.org/http://dx.doi.org/10.23887/jjpgsd.v7i1.16970. 